\title{
Environmental Compensation Used as a Legal Mechanism for the Recovery of an Urban Forest in the State of Rio de Janeiro
}

\author{
Danielle Trindade ${ }^{1}$, Richieri A. Sartori ${ }^{2}$, Marcia Botelho-Silva ${ }^{1}$, Lygia Bicalho ${ }^{3}$ \& Massimo G. Bovini ${ }^{4}$
}

Recebido em 30/09/2019 - Aceito em 12/06/2020

1 Bióloga, Prefeitura da Cidade do Rio de Janeiro, Rio de Janeiro/RJ, Brasil. <trindaded@gmail.com, botelho.smac@gmail.com>.

2 Departamento de Biologia - PUC-Rio, Rua Marquês de São Vicente 225, Prédio Pe. Leonel Franca, 7 Andar, Rio de Janeiro/RJ, Brasil. CEP: 22.451-900. <richierisartori@puc-rio.br>.

3 Estudante de Ciências Biológicas, Departamento de Ecologia, Universidade Federal do Rio de Janeiro, Rio de Janeiro/RJ, Brasil. $<$ ligiabicalho@gmail.com>.

4 Instituto de Pesquisas Jardim Botânico do Rio de Janeiro, Diretoria de Pesquisas, Rua Pacheco Leão 915, Rio de Janeiro/RJ, Brasil. CEP: 22.460-030. <mbovini@jbrj.gov.br>.

\begin{abstract}
The state of Rio de Janeiro has been degraded mainly in lowlands, where protected areas harboring most remaining forests are located. The present study aimed to assess the application of compensatory measures (CM) to restore the vegetation of the Bosque da Barra Municipal Natural Park. We analyzed the survival of planted specimens by dividing the area into six quadrants with approximately nine hectares each. For the analysis, we used a frequency class method and assessed the success rate per quadrant, where 2,125 seedlings of 73 native restinga species were planted. We found 1,245 seedlings, which corresponded to $59 \%$ of the planting. Among those seedlings, 885 were alive, which represented a survival rate of $42 \%$. The average survival per species was $26 \%$. Forty-seven species survived out of 73 planted species. All in all, environmental compensation is an important public policy tool, and this legal device should be used to ensure the restoration of environmental damages, aiming to maintain what establishes the $225^{\text {th }}$ article of the Federal Constitution for present and future generations.
\end{abstract}

Keywords: Bosque da Barra Municipal Natural Park; Compensatory Measure; Environmental Licensing; Protected Areas; Restinga.

\section{A Compensação Ambiental Utilizada como Mecanismo Legal de Recuperação de Floresta Urbana no Rio de Janeiro}

RESUMO - A degradação no estado do Rio de Janeiro vem ocorrendo, principalmente, em áreas baixas, onde grande parte das florestas restantes se encontra em unidades de conservação. $\mathrm{O}$ objetivo deste trabalho foi avaliar a aplicação de recursos de medida compensatória $(\mathrm{MC})$ na restauração da vegetação do Parque Natural Municipal Bosque da Barra. O levantamento da sobrevivência dos espécimes plantados foi analisado através da divisão da área em seis quadrantes com, aproximadamente, nove hectares cada. Para a análise, foi estabelecido um método de classes de frequência, sendo avaliada a taxa de sucesso por quadrante, onde foram plantadas 2.125 mudas de 73 espécies nativas de restinga. Foram encontradas 1.245 mudas, correspondendo a $59 \%$ do plantio. Destas, 885 estão vivas, correspondendo a taxas de $42 \%$ de sobrevivência. A média de sobrevivência por espécie foi de 26\%. A sobrevivência das espécies ocorreu em 47 espécies das 73 plantadas. Em suma, a compensação ambiental é um importante instrumento de política pública, e este dispositivo legal deve ser utilizado de forma a garantir a reparação de danos causados ao meio ambiente com o objetivo de mantê-lo para as presentes e futuras gerações.

Palavras-chave: Licenciamento Ambiental; medida compensatória; Parque Natural Municipal Bosque da Barra; restinga; unidade de conservação.

\section{La Compensación Ambiental Usada como Mecanismo Legal de Recuperación de un Bosque Urbano en Río de Janeiro}

RESUMEN - La degradación en el estado de Rio de Janeiro ha ocurrido principalmente en áreas bajas, en donde gran parte de los remanescentes de bosques se encuentra en unidades de conservación. El objetivo del presente trabajo fue evaluar la aplicación de recursos de medida compensatoria (MC) 
en la restauración de la vegetación del Parque Natural Municipal Bosque da Barra. El levantamiento de la sobrevivencia de los especimenes plantados fue analizada a través de la división del área en seis cuadrantes cada uno de nueve hectares aproximadamente. Para el análisis fue establecido un método de frecuencia de clases evaluando la tasa de exito por cuadrante en donde fueron plantadas 2125 mudas de 73 espécies nativas de la restinga. Se encontraron 1245 mudas que corresponden a $59 \%$ del plantío. De estas, 885 estan vivas correspondiendo a una tasa de $42 \%$ de sobrevivencia. El promedio de la sobrevivencia por espécies fue de $26 \%$. la sobrevivencia de las espécies ocurrio en 47 espécies de las 73 plantadas. En suma, la compensación ambiental es un importante instrumento de política publica, y esta disposición legal debe utilizarse de forma que se garanta la reparación de daños causados al medio ambiente con el objetivo de mantenerlo para las generaciones presentes y futuras.

Palabras clave: Licenciamiento ambiental, Medida de compensación, Parque Municipal Bosque da Barra, Restinga, Unidad de Conservación.

\section{Introduction}

The state of Rio de Janeiro is within the domain of the Atlantic Forest biome and comprises several vegetation types, such as restingas, mangroves, semi-deciduous forests, rainforests, and high-altitude grasslands (campos de altitude). Forest fragments still present in the state of Rio de Janeiro occur mainly in mountainous regions, with poor agricultural potential and difficult access to harbor households; there are not many low mountainous forests anymore, on plains, margins of rivers, lagoons, and coastal ecosystems (Câmara \& Coimbra-Filho 2000; SEMA 2001; Rocha et al. 2003). In the state of Rio de Janeiro, forest remnants are currently reduced to approximately $20 \%$ of their original cover (Fundação SOS Mata Atlântica 2017). Most fragments are at different natural regeneration stages (Maciel \& Magnanini 1989). However, according to Rocha et al. (2003), the state of Rio de Janeiro plays a crucial role in the conservation of the Atlantic Forest because it harbors large blocks of continuous vegetation, which have a high degree of connectivity.

Despite the intense urbanization process, many urban fragments were maintained (Grey \& Deneke 1986) in Rio de Janeiro, and most green areas of the municipality were converted into protected areas (PAs). The PAs are defined and described from the $7^{\text {th }}$ to the $21^{\text {st }}$ article of the SNUC, instituted by the Federal Law \# 9,985, of July 18, 2000 (BRASIL 2000). In the municipality of Rio de Janeiro, the PAs are established in the City Master Plan (PCRJ 2011).

Through environmental compensation, it is possible to reduce environmental degradation by complying with the State's duty to regulate legal standards capable of valuing the compensation properly, using the instruments of the National Environment Policy (BRASIL 1981). It is remarkable the difficulty of environmental agencies in valuing and, above all, in establishing what should be done to restore the environmental damage. However, it is paramount to have efficient and clear legal instruments to compensate damages and ensure an ecologically balanced environment.

The present study aimed to assess the application of compensatory measures (CMs) in the restoration of the vegetation of the Bosque da Barra Municipal Natural Park (hereafter Bosque da Barra), establishing a correlation between environmental degradation in the city and the use of environmental compensation, analyzing plant species used for this experiment. The $\mathrm{CM}$ was created to mitigate plant suppression, resulting from an environmental licensing process in the City of Rio de Janeiro. The resources of this $\mathrm{CM}$ were used in recovery projects of three fully-protected reserves and to produce native restinga seedlings, aiming to replace invasive exotic species with native ones, as the management plans of these protected areas recommend.

\section{Material and Methods Study area}

The Municipal Decree \# 4,105, from June 3, 1983, created the Bosque da Barra (PCRJ 1983). It is a fully-protected reserve (Protected Area PA), comprising an area of 54,398 ha, located in Baixada de Jacarepaguá, in the western region of Rio de Janeiro, Barra da Tijuca (Figure 1). 


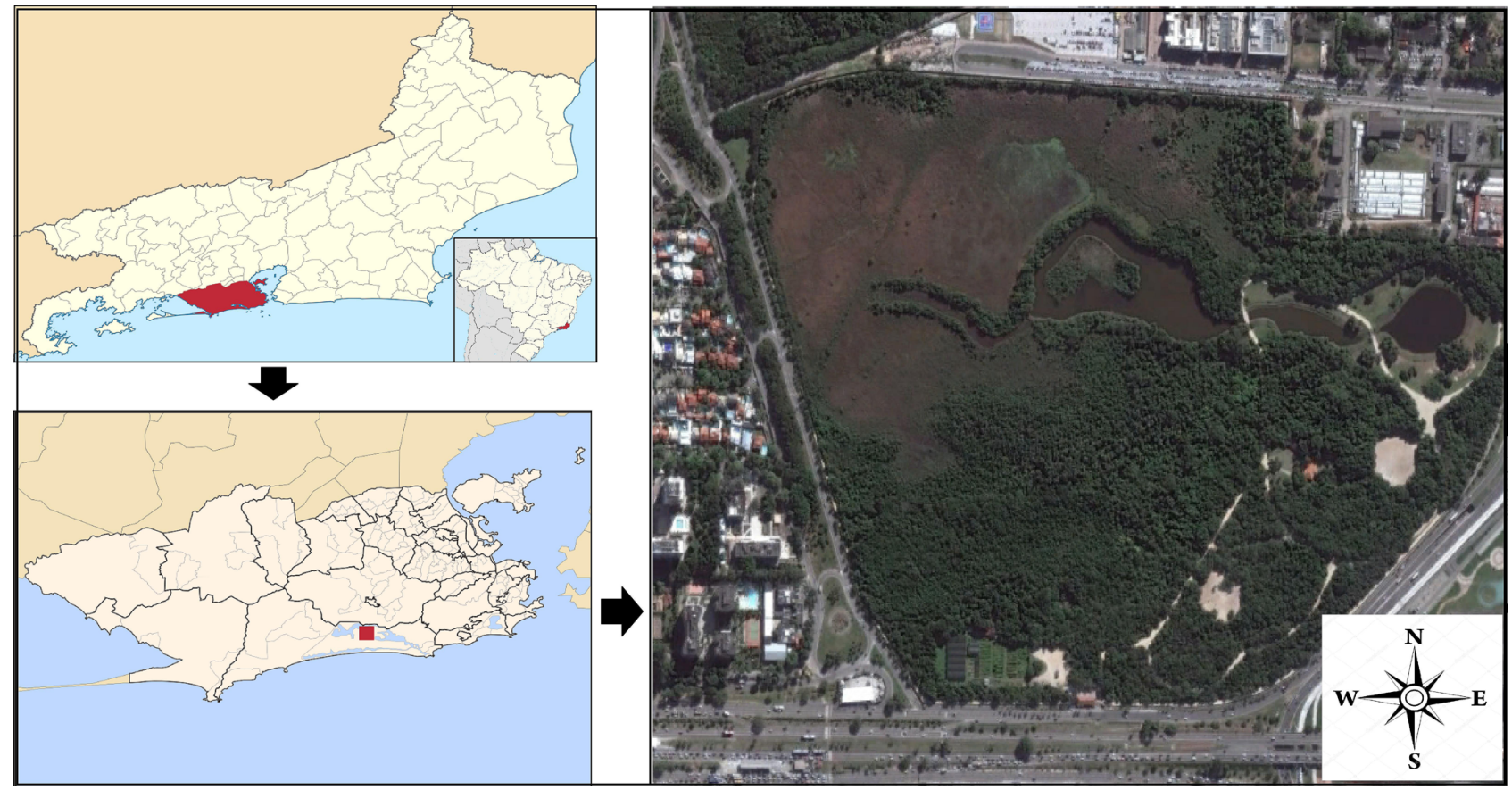

Figure 1 - Map of the location of the study area; Bosque da Barra Municipal Natural Park, Rio de Janeiro, state of Rio de Janeiro. Source: Google Earth Pro® (2017).

\section{Survey of documentary data}

Through the Documentation System database (SIDOC) of the Rio de Janeiro City Government (PCRJ), it was possible to obtain information about the Environmental Licensing process that originated the $\mathrm{CM}$. The $\mathrm{CM}$ was calculated using the data of the vegetation removed for the construction of buildings. The Technical Opinion for this license contains information, such as the number of trees, botanical identification, $\mathrm{CM}$, and monetary value equivalent to all individual trees that have been suppressed, transplanted or preserved based on the current legislation (SMAC Resolution \# 497/2011a). The Public Work Cost System of the Rio de Janeiro City Government (PCRJ) was used to prepare the recovery project budget, as it contains the description of each service and material contracted or acquired, with their respective costs.

The application of this $\mathrm{CM}$ to the Bosque da Barra aimed to comply with the Municipal Program of Invasive Exotic Species Control, created by the Municipal Decree \# 33,814/2011 (SMAC 2011), and the Bosque da Barra Management Plan (SMAC 2014). The project for the partial application of $\mathrm{CM}$ was divided into two phases; first, a floristic inventory and a mapping of invasive exotic species (IES) were carried out by a satellite positioning system (GNSS). Then, the results obtained were used to support the planning of the vegetation management of the Bosque da Barra, with the removal of approximately $9 \%$ of the IES, which were replaced with native restinga species.

The applicant of the licensing process, which generated the $\mathrm{CM}$, hired a private company to carry out this project. The Rio de Janeiro City Government was responsible for monitoring the services performed to certify compliance with the $\mathrm{CM}$.

\section{Field data collection}

Planting carried out between August and November 2014 was analyzed to make an inventory of the survival of the specimens planted in the Bosque da Barra. In the field, the seedlings were identified with seals and non-woven fabric strips, georeferenced (GPS Garmin Vista HCx Etrex), and photographed (Sony Cybershot). Specialists and specific literature were consulted to help with the botanical identification, as the list of planted species was available. The names followed the Flora of Brazil (Flora do Brasil 2020). 
The Microsoft Excel $2010 \AA$ and R programs ( $\mathrm{R}$ Core Team 2017) were used for planting analysis, whereas the Garmin BaseCamp ${ }^{\circledR}$ version 4.6.2 and Google Earth Pro ${ }^{\circledR}$ programs were used for georeferencing.

The area was divided into six quadrants, with approximately 9 ha each, to assess a possible correlation of the survival rate of the seedlings with the place where they were planted, as there are different restinga habitats in the park (sandy plains, wetlands, and floodplains). Planting zones were represented in quadrants 1,2,3 and 4, where 1 and 4 are drylands, while 2 and 3 are sunny open areas, subject to periodic inundation, except at a narrow stretch of approximately $2 \mathrm{~m}$ along the park's main path, where it has been added a thick top layer of clay in the past. Quadrant 4 comprises an area with intense sunlight, where planting took place around the lake, in order to establish a natural fence to keep visitors from disturbing nesting sites and alligators (Figure 2).

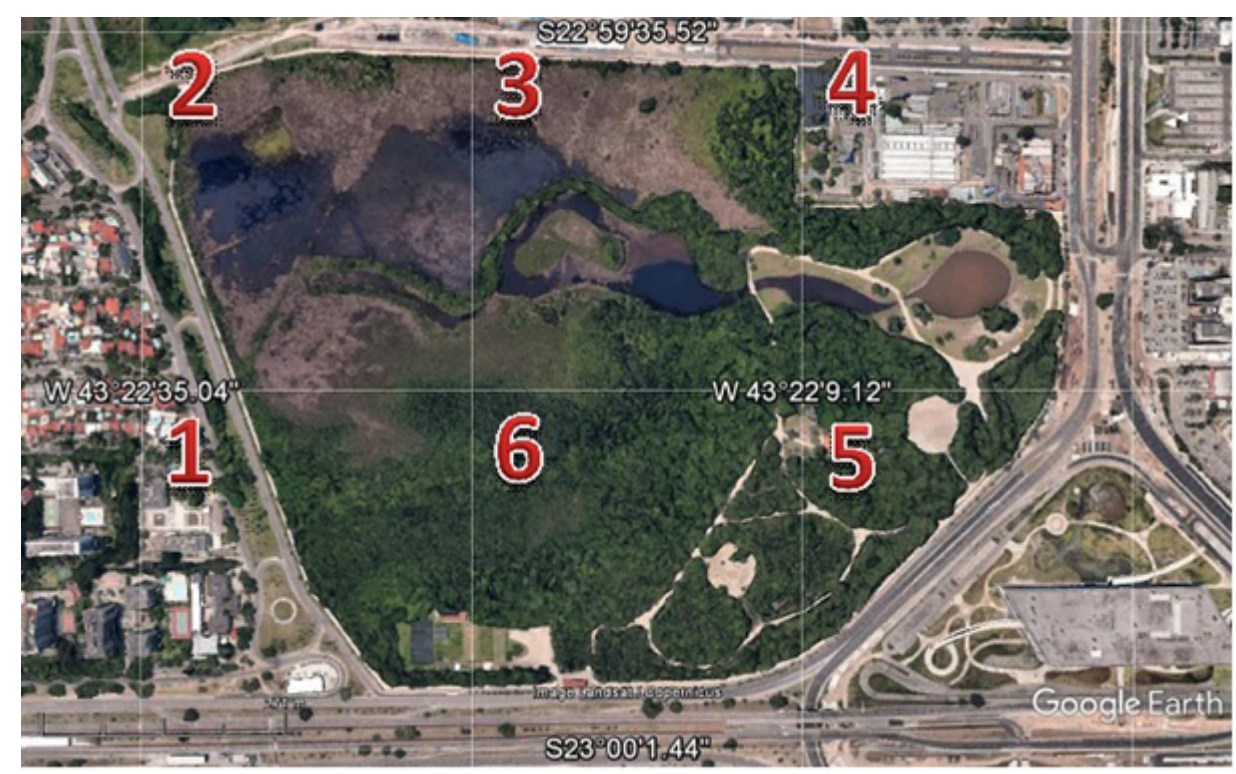

Figure 2 - Study area divided into six quadrants of approximately 9 ha. Bosque da Barra Municipal Natural Park, Rio de Janeiro, state of Rio de Janeiro. Source: Google Earth Pro ${ }^{\circledR}$

There was a high variation in the number of individuals planted per species (one to 154) for no apparent reason, which could make it difficult to analyze the survival rate by species, masking possible success rates and causing errors. A frequency class analysis was used to minimize those differences so that each class was divided from one to 12 according to the number of individuals ( $\mathrm{n}$ ) planted per species. Then, survival was classified into five percentages, within of each of the planting classes, using the Sturges formula (Milone et al. 1995).

The Jaccard index and the UPGMA method were used to assess the success rate per quadrant. In addition, species were divided into classes using as criteria their classification based on the literature: non-pioneer, pioneer, and dead.

\section{Results and Discussion}

\section{Tree suppression in the Environmental Licensing Process}

The area subjected to the environmental license has $8,395.69 \mathrm{~m}^{2}$ and the damages the construction caused involved land movement and impact on the fauna and flora. The number of seedlings to be planted as a compensatory measure is calculated through factors that consider characteristics of the species to be removed, for example, if they are exotic, native, and endangered and their size. In the case studied, a CM of 6,180 seedlings was calculated based on the removal of 188 trees and a CM of 1000 seedlings, in the case of transplant failure, required for 32 trees. The monetary value per seedling is $\$ 50,00$ 
(following the current legislation). Therefore, the total value of the $\mathrm{CM}$ was $\$ 312.755,00$, and the $\mathrm{CM}$ of transplantation summed $\$ 50.607,00$. This amount serves for debt collection in case the applicant does not comply with the commitment term signed in the licensing process.

The results showed a high environmental impact index in the area, as $77 \%$ of the tree cover was allowed to be suppressed, $67 \%$ native. The surrounding comprises an area of medium urban density near the Pedra Branca State Park, which increases the environmental impact on the area.

\section{Assessment of the survival of planted seedlings}

The priority of the restoration project was to use a high diversity of native restinga species to offer a broad range of resources for the fauna and was not designed with the objective to carry out experimental tests. In this project, from the 6,180 seelings related to the CM, 2,125 seedlings of 73 native species of restinga were planted following traditional planting procedures, of which 17 were endangered (Di Maio \& Botelho-Silva 2000), the remaining seedlings were distributed to other protected areas. The number of individuals per species was determined by the availability of seedlings in the municipal plant nursery; thus, it was not homogeneous. There are 28 species with less than ten individuals. Despite its value as a conservation effort, considering the representation of rare species, this procedure hindered the analysis of the success rate.

In the field, 1,245 seedlings were found, which corresponded to $59 \%$ of the planting. Of these plants, 885 were alive and 360, dead, which represented a survival rate of $42 \%$. For statistical purposes, the seedlings not found were considered dead, totaling 1,240 (58\%). The average survival per species was $26 \%$. It is worth mentioning that out of 885 seedlings found alive, 81 could not be identified, for the poor development of the individual.

The causes of seedling mortality were probably the lack of maintenance in the plantation in the following years, allied with the El Niño climatic phenomenon that occurred at the end of 2014 , causing high temperatures and low rainfall. Technicians of the city government detected in inspections that the water stress has dried up the lake and the flooded areas in the park.
In the field, it was possible to detect the development of IES, from the seed bank in the soil, where leucenas (Leucaena leucocephala) stood out. There were also large leucenas on the public road, outside the park, with enough height to contribute to dispersion. It is worth highlighting that IES have a high degree of adaptation and invasion, as well as accelerated growth. Another important factor observed was the massive amount of leaf litter adjacent to the visitation area. This accumulation of leaf litter occurs because the employees of the Municipal Company for Urban Cleaning (Comlurb), responsible for cleaning the visitation area, sweep the leaves on the ground to the planting area. This procedure decreases the chances of seedling survival due to suffocation. However, this low survival rate seems to be particularly evident in an area dominated by Malvaviscus (Malvaviscus arboreus Cav.), exotic species that multiplies rapidly when planted, where no planted seedlings were found.

\section{Survival of individuals per quadrant}

In quadrant " 1 ", of 175 seedlings plotted, 104 were alive and 71, dead, i.e., a survival rate of 59\%. In quadrant "2", of 194 seedlings plotted, 116 were identified alive and 78, dead, representing a survival rate of $60 \%$. In quadrant "3", of 288 seedlings plotted, 193 were alive and 95 , dead, indicating a survival rate of $67 \%$. In quadrant "4", of 588 seedlings plotted, 472 were identified alive and 116, dead, i.e., a survival rate of $80 \%$. The average survival rate per quadrant was $66.5 \%$, and the difference between live and dead individuals is shown in a chart (Figure 3).

The analysis carried out with the Jaccard index and the UPGMA method showed a correlation of $98.5 \%$ between quadrants. The result is shown in the dendrogram (Figure 4), in which the quadrants " 1 " and " 2 " show great similarity and their survival rates are also similar; approximately $60 \%$ and $59 \%$, respectively. This similarity could also be observed in the field, expressed as shading conditions, vegetation type, and size of individual trees. In quadrant " 2 ", it was possible to observe groups of dead individuals in specific places due to a high infestation of Malvaviscus in these areas. In other quadrants, this condition was more interleaved. 


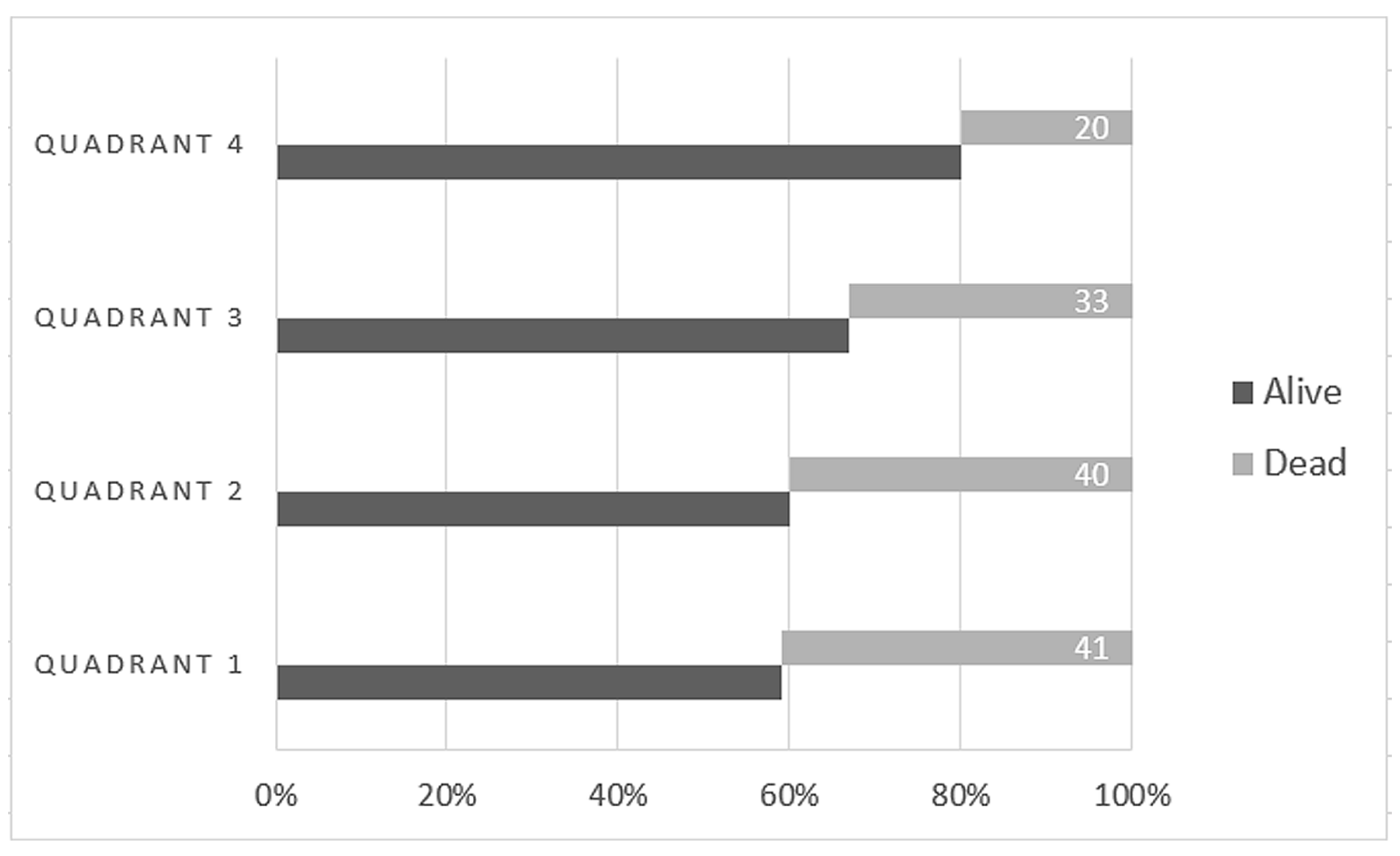

Figure 3 - Comparison of live and dead seedlings per quadrant in the Bosque da Barra Municipal Natural Park.

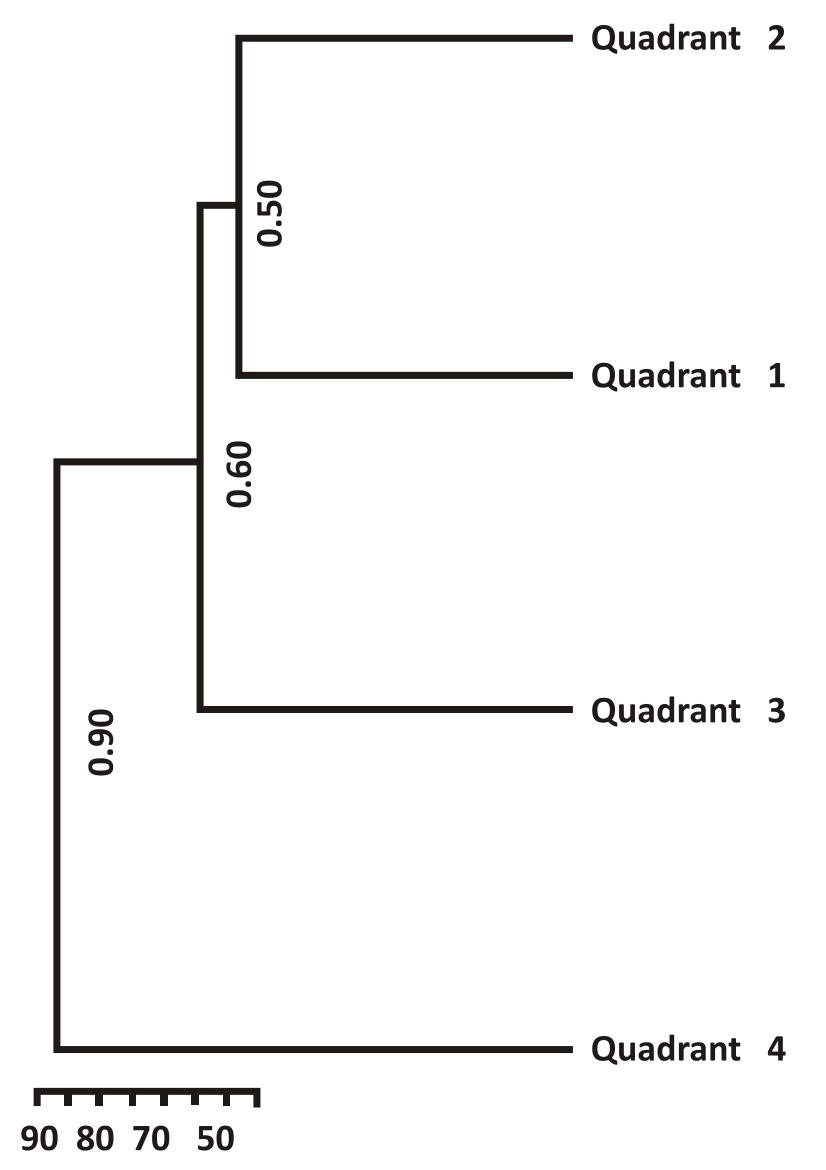

Figure 4 - Dendrogram representing the similarity of planting per quadrants in the Bosque da Barra Municipal Natural Park. 
It is worth mentioning that quadrant " 4 " is the most different, as most seedlings were planted around the lake, whose abiotic conditions differ from other quadrants. In addition, seedlings were not affected by IES and excessive leaf litter. These factors may have resulted in a higher survival rate (80\%). Clusia fluminensis; Heteropterys coleoptera, Senna appendiculata, and Sophora tomentosa were planted to form a hedgerow to prevent visitors from accessing this area, which is the nesting site of the southern lapwing Vanellus chilensis.

No seedling of Heteropterys coleoptera was found. As the planting around the lake was carried out with spacing between seedlings, competition between them cannot have caused the death of Heteropterys coleoptera. The fact that it is an open area, susceptible to wind, may have contributed to the death of this species.

\section{Species representing survival}

Forty-seven of 73 species planted in the Bosque da Barra survived, i.e., in $64 \%$ of the species at least one individual was found alive. However, species were divided into classes to reduce possible statistical failures. In addition, for a better analysis, survival was classified into five percentage categories within each of the planting classes and represented in a chart (Figure 5).

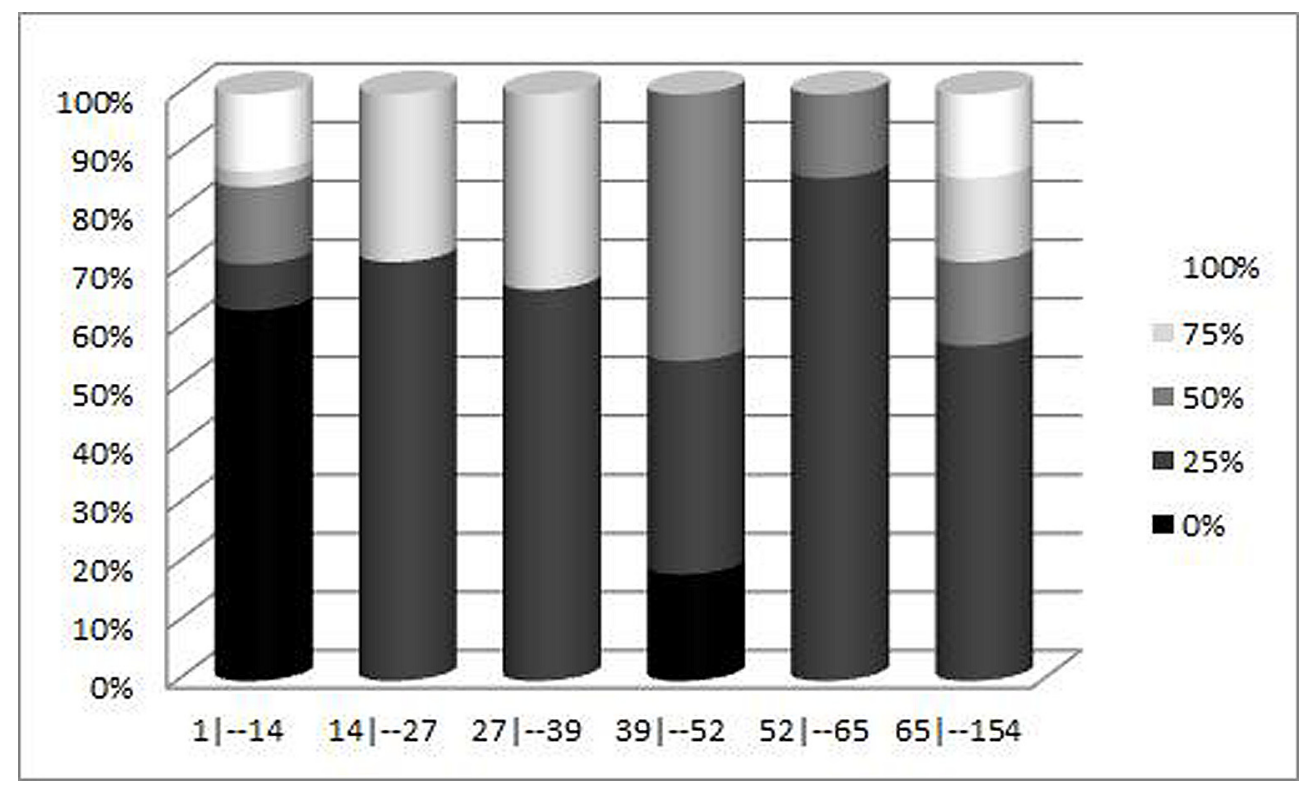

Figure 5 - Survival rate of species divided into classes planted in the Bosque da Barra Municipal Natural Park divided into five percentage classes.

In the survival analysis by successional stage, the highest survival rate occurred among pioneers; $59 \%$ and, $41 \%$ for non-pioneers. It is worth mentioning that pioneers were better represented in the planting - 43 species are classified as pioneers.

Still regarding survival rate per class, the present study adopted as a pattern of success the species that showed at least $50 \%$ of survival (Table 1 ). Thus, it was possible to identify and analyze the success rate of some species. Besides, it was possible to represent in a chart the data of survival success per class (Figure 6). Seven species showed an index equal to or above $50 \%$ of survival; 7 species were between $40 \%$ and $20 \%$, and 24 species had a percentage equal to zero. Byrsonima sericea, for example, achieved the highest success rate for class 1 with $100 \%$ success. This species is abundant in restingas (Araujo 2000, Pereira et al. 2001) and its main characteristics are: semideciduous, heliophytic or sciophytic, selective hygrophytic, and pioneer (Lorenzi 2002). Sá (1996) analyzed the regeneration of an area of restinga forest in the Jacarepiá State Ecological Reserve (Saquarema, RJ) and concluded that Byrsonima sericea is among the five species of 
highest importance value, based on an study carried out for six years in an area disturbed by tractors. Such evidence indicates some resistance of this species in disturbed areas. Vitex polygama, which showed $50 \%$ of success in the same class, is a deciduous or semi-deciduous, heliophytic, pioneer plant (Lorenzi 2002). The individuals of this species were found in quadrants " 2 " and " 3 ". As this species requires total solar exposure, its success can be related to the habitat as, through geographic coordinates, it was possible to verify that these individuals are in a large clearing area.

In the present study, Coccoloba arborescens obtained $74 \%$ of survival in group 2. Montezuma \& Araujo (2007) recorded the presence of this species in an area with Floodable Shrubby vegetation in the Jurubatiba Restinga National Park, Rio de Janeiro. Penhalber \& Vani (1997) affirmed that Coccoloba arborescens is among the most abundant species in the tree component of Fontes do Ipiranga State Park, located in the metropolitan region of São Paulo, state of São Paulo. This species was found mainly in quadrants " 2 " and " 3 " in Bosque da Barra, but individuals found alive were randomly distributed, either contiguous or not to the flooded area of the park. In addition, as already mentioned in the present study, the park is suffering from water stress, and despite that, Coccoloba arborescens obtained survival success, which can evidence that regardless of its probable dependence to flooded areas, this species is resistant to water variations.

In class 3 , there was a clear discrepancy in success rates among species, as Bromelia antiacantha showed $70 \%$ of success, whereas Pseudobombax grandiflorum and Eugenia copacabanensis showed $10 \%$ and $9 \%$ of success, respectively. The high survival rate of Bromelia antiacantha may be related to its rusticity and plasticity. Rocha-Pessoa et al. (2008), during their study in the restinga of Arraial do Cabo, Rio de Janeiro, found a high frequency of this species in a closed wrack zone, which can indicate tolerance to high salinities, characteristic of this vegetation zone. It is worth mentioning that the individuals found alive were in the quadrant " 3 ", i.e., in a shaded area and a closed forest.

Statistical analyses showed no success in the survival rate for classes 4 and 5. Tonetti (2015) studied the diet of the capybara (Hydrochoerus hydrochaeris) present in the park area and identified the food preference of this animal for species of the families Poaceae, Myrtaceae, and Asteraceae. The study comprised 11 Myrtaceae species, including Eugenia spp. present in both classes 4 and 5 , in which all species showed a low success rate. Álvarez \& Kravetz, (2002) explain that the capybara is extremely selective in its choice of plants, which suggests a certain connection between the low survival of these species in the area. A species worth noting in class 4 is Passiflora mucronata with $0 \%$ survival. It is possible that the low index resulted from the difficulty of observation in the field as this species is a liana and, therefore, we can infer that no support was placed for these individuals. Hence, this result may not represent the survival of Passiflora mucronata in the area correctly. We can also include other species difficult to observe in the field due to the possible lack of support to identify the seedlings planted in the present study: Passiflora edulis and Canavalia parviflora. These species are class 1 and showed zero survival rate. Junior-Pereira et al. (2007) describe that Allagoptera arenaria, for example, can somewhat easily occupy altered areas of restinga in the state of Rio de Janeiro. Hence, it is possible that this species may have survived planting.

In class 6, two species showed a high success rate: Senna appendiculata and Sophora tomentosa. Pereira \& Araújo (1995) cite the presence of Senna appendiculata in inter-bush areas of flooded open shrubby vegetation. They also report that inter-bush regions usually comprise areas with no vegetation cover. However, Braz et al. (2013) in their study on the restinga of the "Das Neves" beach, located in the state of Espirito Santo, cited the presence of Senna appendiculata in restinga regions with no-flooded open shrubby vegetation. They also included other plants typical of this vegetation type, such as Byrsonima sericea, Cupania emarginata, Protium icicariba, and Clusia fluminensis present also in Bosque da Barra. Chagas et al. (2014) reported that this species occurs on the edges of the thickets of flooded and no-flooded open shrubby vegetation. It also occupies the surroundings of the flooded herbaceous vegetation, non-flooded forest, and flooded forest, and occasionally the interior of forests, when the light is favorable. Those studies suggest that the relevant factor for the best development of these species is light; therefore, we can correlate the survival success of Senna appendiculata with the site it was 
planted, mostly around the lake, i.e., an open area with high sun exposure.

Sophora tomentosa occurs on the coast of all tropicalregions of theworld(Peñaetal.2000).Santos et al. (2001) suggested its use in the reforestation of degraded areas with high salt concentration. This species is typical of herbaceous or subshrub restinga (Bresolin 1979). Reis-Duarte (2004) warns that soil characteristics, their humidity content, and fertility can be considered important abiotic factors associated with the stability and recovery potential of restingas. The author showed in this study that Sophora tomentosa is abundant in dry scrub areas, preferably in clearings. In addition, Reis-Duarte (2004) highlights the phenological plasticity of Alchornea triplinervia, because it occurs in all physiognomies of the arboreal-shrubby restinga of Restinga das Palmas, despite its preference for humid seasonally flooded soils. Other species also cited as having a preference for humid soils and habitats are: Pera glabrata. Psidium cattleianum, Psychotria carthagenensis, Tabebuia cassinoides, Guapira opposita, and Senna pendula. This result contributes to a possible correlation between the high mortality rate of these species, influenced by edaphic conditions, and the water stress of the region, thereby affecting their survival in the area. In contrast, the high success rate of Sophora tomentosa may be related to the planting site, as all individuals of this species were planted in the quadrant " 4 ", which suggests that the success may be related to the high incidence of sunlight and dry scrub areas.

Table 1 - Survival rate of species planted in Bosque da Barra Municipal Natural Park by classes.

\begin{tabular}{|c|c|c|c|c|c|c|}
\hline \multirow{2}{*}{ Species } & \multicolumn{6}{|c|}{ Classes } \\
\hline & 1 & 2 & 3 & 4 & 5 & 6 \\
\hline Allophylus puberulus (Cambess.) Radlk. & & $5 \%$ & & & & \\
\hline Andira legalis (Vell.) Toledo & $25 \%$ & & & & & \\
\hline Aspidosperma parvifolium A.DC. & & & & $28 \%$ & & \\
\hline Bromelia antiacantha Bertol. & & & $70 \%$ & & & \\
\hline Byrsonima sericea DC. & $100 \%$ & & & & & \\
\hline Calyptranthes brasiliensis Spreng. & $33 \%$ & & & & & \\
\hline Chamaecrista ensiformis (Vell.) H.S.Irwin \& Barneby & $100 \%$ & & & & & \\
\hline Clusia fluminensis Planch. \& Triana & & & & & & $46 \%$ \\
\hline Clusia lanceolata Cambess. & & $21 \%$ & & & & \\
\hline Coccoloba alnifolia Casar. & & $25 \%$ & & & & \\
\hline Coccoloba arborescens (Vell.) R.A.Howard & & $74 \%$ & & & & \\
\hline Connarus nodosus Baker & & & & $4 \%$ & & \\
\hline Crateva tapia L. & $100 \%$ & & & & & \\
\hline Cynophalla flexuosa (L.) J.Presl & $60 \%$ & & & & & \\
\hline Erythroxylum ovalifolium Peyr. & & & & $29 \%$ & & \\
\hline Esenbeckia grandiflora Mart. & $40 \%$ & & & & & \\
\hline Eugenia astringens Cambess. & & & & & $22 \%$ & \\
\hline Eugenia brasiliensis Lam. & & & & & & $13 \%$ \\
\hline Eugenia copacabanensis Kiaersk. & & & $9 \%$ & & & \\
\hline Eugenia selloi (O. Berg) B.D. Jacks. & & & & $44 \%$ & & \\
\hline Eugenia sulcata Spring ex Mart. & & & & & & $6 \%$ \\
\hline Eugenia uniflora L. & & & & & $16 \%$ & \\
\hline Ficus clusiifolia Schott & $40 \%$ & & & & & \\
\hline
\end{tabular}




\begin{tabular}{|c|c|c|c|c|c|c|}
\hline \multirow{2}{*}{ Species } & \multicolumn{6}{|c|}{ Classes } \\
\hline & 1 & 2 & 3 & 4 & 5 & 6 \\
\hline Fridericia conjugata (Vell.) L.G.Lohmann & $25 \%$ & & & & & \\
\hline Garcinia brasiliensis Mart. & & & & & $7 \%$ & \\
\hline Guapira opposita (Vell.) Reitz & & & & & $9 \%$ & \\
\hline Handroanthus chrysotrichus (Mart. ex DC.) Mattos & & & & $14 \%$ & & \\
\hline Heteropterys coleoptera A.Juss. & & & & & & $1 \%$ \\
\hline Inga maritima Benth. & & & & & $9 \%$ & \\
\hline Kielmeyera membranacea Casar. & & & & $7 \%$ & & \\
\hline Machaerium lanceolatum (Vell.) J.F.Macbr. & $100 \%$ & & & & & \\
\hline Maytenus obtusifolia Mart. & & & & & $25 \%$ & \\
\hline Myrcia multiflora (Lam.) DC. & & & & & $5 \%$ & \\
\hline Myrcia racemosa (O.Berg) Kiaersk. & & $60 \%$ & & & & \\
\hline Myrrhinium atropurpureum Schott & & & & $44 \%$ & & \\
\hline Myrsine umbellata Mart. & & & & $10 \%$ & & \\
\hline Neomitranthes obscura (DC.) N.Silveira & & & & $30 \%$ & & \\
\hline Pseudobombax grandiflorum (Cav.) A.Robyns & & & $10 \%$ & & & \\
\hline Psidium cattleianum Sabine & & & & & & $9 \%$ \\
\hline Psychotria carthagenensis Jacq. & & $10 \%$ & & & & \\
\hline Schwartzia brasiliensis (Choisy) Bedell ex Gir.Cañas & & $8 \%$ & & & & \\
\hline Senna appendiculata (Vogel) Wiersema & & & & & & $90 \%$ \\
\hline Sophora tomentosa L. & & & & & & $52 \%$ \\
\hline Talipariti pernambucense (Arruda) Bovini & $38 \%$ & & & & & \\
\hline Trichilia casaretti C.DC. & $100 \%$ & & & & & \\
\hline Vitex polygama Cham. & $50 \%$ & & & & & \\
\hline Zollernia glabra (Spreng.) Yakovlev & $20 \%$ & & & & & \\
\hline
\end{tabular}

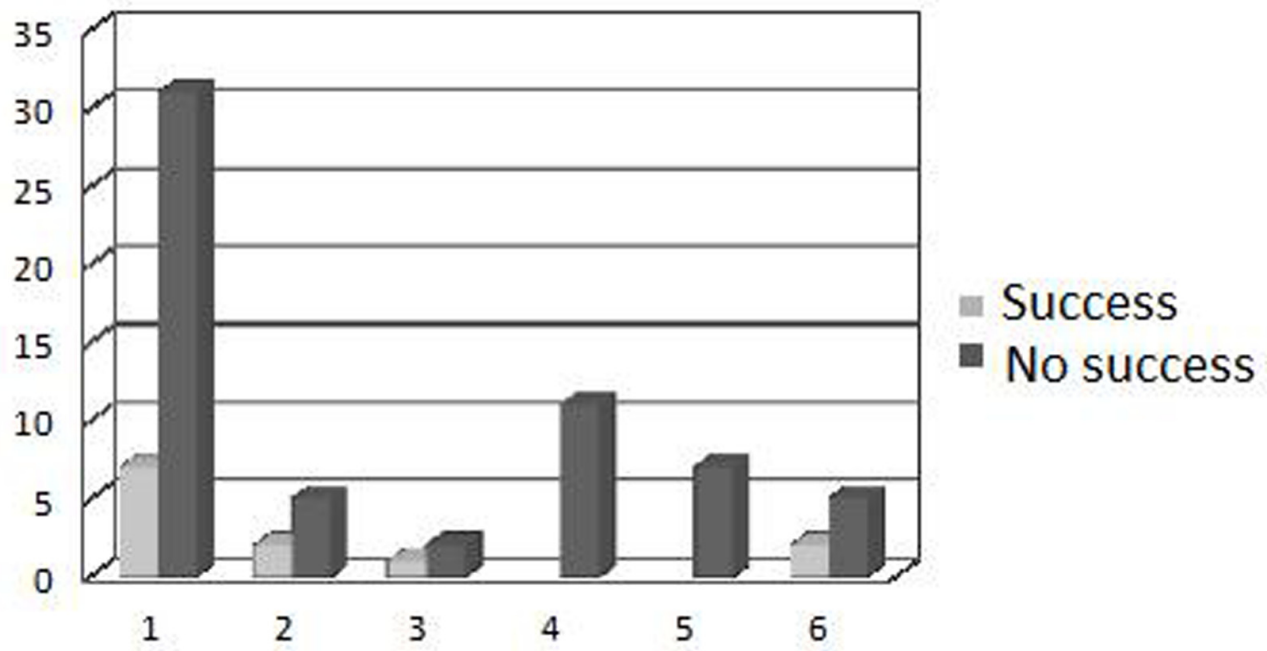

Figure 6 - Comparative chart of species success divided by classes. 


\section{Conclusions}

Environmental compensation in PAs was established on the $3^{\text {rd }}$ paragraph of the $36^{\text {th }}$ article of the law \# 9,985, of July 18, 2000 (BRASIL 2000). This law regulates the $225^{\text {th }}$ article, first paragraph, items I, II, III, and VII of the Federal Constitution, establishing the National System of Natural Protected Areas. Despite the legislative provision for environmental compensation, there is no consensus on this critical public policy instrument, as this law does not include a clear methodology for the application of this compensation. In addition, after the promulgation of the Complementary Law \# 140 of December 8, 2011 (BRASIL 2011), which granted autonomy to the executive bodies that comprise the National Environmental System (Sisnama) regarding the competence to provide environmental licensing, it was possible for each State and Municipality to define their own criteria and calculations for environmental compensation, thus increasing the legal discrepancy concerning this matter. In the municipality of Rio de Janeiro, the calculation of environmental compensation is described in a specific legal standard and, contrary to what was defined in the $36^{\text {th }}$ article of law \# 9,985, of 2000 (BRASIL 2000), the current legislation is centered in the valuation based on the species origin and endemism and the size of tree individuals. In addition, such environmental compensation is not necessarily intended to support the implementation and maintenance of the Protected Area of the Full Protection Group as provided by the SNUC. In the present study, the resources from the $\mathrm{CM}$ were used in the maintenance of three fully-protected reserves.

Regarding the legal orientation about environmental restoration projects, the municipality of Rio de Janeiro lacks this point. The state of São Paulo, for example, determines, through Resolution, guidelines for the heterogeneous reforestation of degraded areas (SMA 2008). Despite the lack of specific legislation, the projects are prepared by the Secretariat technicians and based on scientific literature and professional experience.

During the present study, we sought to report the operationalization of the environmental compensation to clarify and disseminate information about the application of public resources and their results in protected areas. We could conclude that there is a need for management and funding by the government to maintain protected areas. Hence, it was possible to infer that among the possible causes of the low survival of the species planted in the Bosque da Barra, was the lack of previous studies about the soil and light conditions, and the absence of maintenance of the planted seedlings in the subsequent years. We also observed that there was no distribution pattern of individuals of the same species in different areas, possibly including species unsuitable for a particular area.

In the present study, we could indicate among the species that showed a high success rate, which ones are more resistant or have specific ecological characteristics that can contribute to their success. This information contributes to better management of the program, optimizing environmental compensation resources. Species that have achieved a high success rate can be used as key pieces in the restoration of a similar area.

Furthermore, the large variation in the number of individuals planted per species may be directly related to survival rates. According to Pereira et al. (2012), intercropping is very favorable in many species, but secondary and climax species are to be separated, as they belong to a specific ecological group.

It is well known that the maintenance of protected areas demands commitment in the allocation of human and financial resources. All in all, environmental compensation is an important public policy tool, and this legal device should be used to ensure the restoration of environmental damages, aiming to maintain what establishes the $225^{\text {th }}$ article of the Federal Constitution for present and future generations. We hope the present study has relevance to be used as technical support in similar areas.

\section{Acknowledgements}

The authors are grateful to the Professional Masters course of Biodiversity in Conservation Units of Escola National de Botânica Tropical, to the Municipal Secretariat for Environment of Rio de Janeiro City Hall, particularly the managers of Bosque da Barra Municipal Natural Park, Ernani Bellon for the elaboration of figures, and finally to the biologist Carlos Daniel M. Ferreira for field work support. 


\section{References}

Álvarez MR \& Kravetz FO. La cría de carpinchos (Hydrochoerus hydrochaeris) em cautiverio dentro del processo de diversificación agropecuaria. Nowet, 1: 44-49, 2002.

Araújo DSD. 2000. Análise florística e fitogeográfica das restingas do Estado do Rio de Janeiro. Tese (Doutorado em Ecologia). Universidade Federal do Rio de Janeiro. 176p.

Brasil. 1967. Lei nº 6.938, de 31 de agosto de 1981. Diário Oficial da União. <http://www.planalto.gov.br/ccivil _03/ Leis/L6938compilada.htm> . Acess on: 06/09/2018.

Brasil. 2000. Lei $\mathrm{n}^{\circ}$ 9.985, de 18 de julho de 2000. Diário Oficial da União. <http://www.planalto.gov.br/ ccivil_03/LEIS/L9985.htm> Acess on: 06/09/2018.

Brasil. 2011. Lei Complementar $n^{\circ} 140$, de 08 de dezembro de 2011. Diário Oficial da União. <http:// www.planalto.gov.br/cciVil_03/Leis/LCP/Lcp140.htm> Acess on: 06/09/2018.

Braz DM et al. Restinga da Praia das Neves, ES, Brasil: caracterização fitofisionômica, florística e conservação. Biota Neotropica, 13: 314-331, 2013.

Bresolin A. Flora da restinga da llha de Santa Catarina. Insula, 10: 3-54, 1979.

Chagas AP, Peterle PL, Thomaz LD, Dutra VF \& Valadares RT. Leguminosae-Caesalpinioideae do Parque Estadual Paulo César Vinha, Espírito Santo, Brasil. Rodriguésia, 65: 99-112, 2014.

Câmara IG \& Coimbra-Filho AF. 2000. Proposta para uma política de conservação ambiental para o Estado do Rio de Janeiro. In: Bergallo HG, Rocha CFD, Alves MAS \& Van Sluys M. (orgs.). A Fauna ameaçada de extinção do Estado do Rio de Janeiro. Editora da Universidade do Estado do Rio de Janeiro. 168p.

Cogliatti-Carvalho L, Freitas AFN, Rocha CFD \& Van Sluys M. Variação na estrutura e na composição de Bromeliaceae em cinco zonas de restinga no Parque Nacional da Restinga de Jurubatiba, Macaé, RJ. Revista Brasileira de Botânica, 24: 1-9, 2001.

Di Maio FR \& Botelho-Silva M. 2000. Espécies ameaçadas de extinção no Município do Rio de Janeiro: Fauna e Flora. 1 ed. Secretaria Municipal de Meio Ambiente. 66p.

FLORA DO BRASIL 2020 em construção. Jardim Botânico do Rio de Janeiro. <http://floradobrasil.jbrj. gov.br/> Acess on: 06/09/2018.

Fuhro D, Vargas D \& Larocca J. Levantamento florístico das espécies herbáceas, arbustivas e lianas da floresta de encosta da Ponta do Cego, Reserva Biológica do Lami (RBL), Porto Alegre, Rio Grande do Sul, Brasil. Pesquisas, ser. Botânica, 56: 239-256, 2005.
Fundação SOS Mata Atlântica e Instituto Nacional de Pesquisas Espaciais. 2017. Atlas dos remanescentes florestais da Mata Atlântica período 2016-2017. Fundação SOS Mata Atlântica e INPE. 68p.

Grey GW \& Deneke FJ. 1986. Urban Forestry. 2 ed. John Wiley. 299p.

Junior-Pereira J, Moreira ACC, Hottz D, Paula RR, Somner GV \& Menezes LFT. Análise Estrutural de uma Formação Vegetal Arbustiva Aberta na Restinga da Marambaia - RJ. Revista Brasileira de Biociências, 5(1): 366-368, 2007.

Lorenzi RH. 2002. Árvores Brasileiras: Manual de identificação e cultivo de plantas arbóreas nativas do Brasil. Vol. 2. 4 ed. Editora Plantarum. 384p.

Maciel NC \& Magnanini A. Recursos Faunísticos do Estado do Rio de Janeiro. Boletim FBCN 24: 65-98, 1989.

Milone G \& Angelini F. 1995. Estatística aplicada. 1 ed. Atlas Editora. 139p.

Montezuma RCM \& Araujo DSD. Estrutura da vegetação de uma restinga arbustiva inundável no Parque Nacional da Restinga de Jurubatiba, Rio de Janeiro. Pesquisas, ser. Botânica, 58: 157-176, 2007.

PCRJ (Prefeitura da Cidade do Rio de Janeiro), 1983. Decreto $n^{\circ} 4.105$, de 03 de junho 1983. Diário Oficial do Município do Rio de Janeiro < http://www.jusbrasil. com.br/diarios/83346689/dom-jr-normal-05-06-2014pg-52> (Acess on: 03/04/2018).

PCRJ (Prefeitura da Cidade do Rio de Janeiro), 2011. Lei Complementar $n^{\circ} 111$, de $1^{\circ}$ de fevereiro de 2011. Diário Oficial do Município do Rio de Janeiro, <http:// www.rio.rj.gov.br/dlstatic/10112/4000307/4117400/ lei_compl_111.pdf > (Acess on 05/2018).

Pereira MCA, Araújo DSD \& Pereira OJ. Estrutura de uma comunidade arbustiva da Restinga de Barra de Maricá - RJ. Rev. Brasil. Bot., 24: 273-281, 2001.

Pereira JS, Abreu CFN, Junior RA \& Rodrigues SC. Avaliação do índice de sobrevivência e crescimento de espécies arbóreas utilizadas na recuperação de área degradada. Revista Geonorte, Edição Especial, 1(4): 138-148, 2012.

Peña RC, Iturriaga L, Montenegro G \& Cassels BK. Aspectos filogenéticos y biogeográficos de Sophora sect. Edwardsia (Papilionatae). Pacific Science, 54(2): 159-167, 2000.

Penhalber EF \& Vani WM. Floração e chuva de sementes em mata secundária em São Paulo, SP. Rev. Brasil. Bot., 20(2): 205-220, 1997.

Pereira OJ \& Araújo DSD. Estrutura da vegetação de entre moitas da formação aberta de Ericaceae no Parque Estadual de Setiba, ES. Oecologia Brasiliensis, 1: 245-257, 1995. 
Reis-Duarte RM. 2004. Estrutura da floresta de restinga do Parque Estadual da Ilha Anchieta (SP): bases para promover o enriquecimento com espécies arbóreas nativas em solos alterados. Tese (Doutorado em Biociências). Universidade Estadual Paulista. 104p.

Rocha CFD, Bergallo HG, Alves MAS \& Van Sluys M. 2003. A biodiversidade nos grandes remanescentes florestais do Estado do Rio de Janeiro e nas restingas da Mata Atlântica. Rima Editora. 134p.

Rocha-Pessoa TC, Nunes-Freitas AF, Cogliatti-Carvalho L. \& Rocha CF. Species composition of Bromeliaceae and their distribution at the Massambaba restinga in Arraial do Cabo, Rio de Janeiro, Brazil. Brazilian Journal of Biology, 68(2): 251-257, 2008.

Sá CFC. Regeneração em uma área de floresta de restinga na Reserva Ecológica Estadual de Jacarepiá. Arquivos do Jardim Botânico do Rio de Janeiro, 34(1): 177-192, 1996.

Santos EC, Goi SR \& Neto JJ. Proposta de utilização de Sophora tomentosa L. subespécie littoralis (Schrad) Yakove para recuperação de áreas com resíduo industrial salino. Floresta e Ambiente, 8(1): 216-218, 2001.

SEMA (Secretaria de Estado de Meio Ambiente e Desenvolvimento Sustentável). 2001. Rio de Janeiro: Atlas das Unidades de Conservação da Natureza do Estado do Rio de Janeiro. Governo do Estado do Rio de Janeiro. Metalivros. 48p.
SMA (Secretaria de Meio Ambiente do Estado de São Paulo), 2008. Resolução SMA n ${ }^{\circ} 008$, de 31 de janeiro de 2008. Diário Oficial do Estado de São Paulo < https:// smastr16.blob.core.windows.net/resolucao/2008/2008_ res_est_sma_08.pdf $>$. Acess on: 05/2018.

SMAC (Secretaria Municipal de Meio Ambiente da Cidade do Rio de Janeiro), 2011. Decreto n 33.814, de 18 de maio de 2011. Diário Oficial do Município do Rio de Janeiro <https://eismunicipais.com.br/a1/rj/r/riode-janeiro/decreto/2011/3381/33814/decreto-n-338142011-dispoe-sobre-o-programa-municipal-de-controlede-especies-exoticas-invasoras $>$. Acess on: 05/2018.

SMAC (Secretaria Municipal de Meio Ambiente da Cidade do Rio de Janeiro), 2011a. Resolução SMAC n 497, de 06 de setembro de 2011. Diário Oficial do Município do Rio de Janeiro < https://ecozone.files.wordpress.com/2014/07/ resoluc3a7c3a3o-492011-autorizac3a7c3a3o-devegetac3a7c3a3o.pdf> . Acess on: 05/2018.

SMAC (Secretaria Municipal de Meio Ambiente da Cidade do Rio de Janeiro), 2014. Resolução SMAC n ${ }^{\circ}$ 559, de 04 de junho de 2014. <https:/www.jusbrasil. com.br/diarios/83346689/dom-rj-normal-05-06-2014pg-52>. Acess on: 05/2018.

Tonetti AM \& Biondi D. Dieta de capivara (Hydrochoerus hydrochaeris, Linnaeus, 1766) em ambiente urbano, Parque Municipal Tingui, Curitiba - PR. Acta Veterinaria Brasilica, 9(4): 316-326, 2015.

Biodiversidade Brasileira - BioBrasil.

Edição temática: Diálogos entre a Academia e a Gestão de Áreas Protegidas:

Programa de Pós-Graduação Profissional - Biodiversidade em Unidades de Conservação

$$
\text { n. 2, } 2020
$$

http://www.icmbio.gov.br/revistaeletronica/index.php/BioBR

Biodiversidade Brasileira é uma publicação eletrônica científica do Instituto Chico Mendes de

Conservação da Biodiversidade (ICMBio) que tem como objetivo fomentar a discussão e a disseminação de experiências em conservação e manejo, com foco em unidades de conservação e espécies ameaçadas.

ISSN: 2236-2886 